\title{
PROFESSIONAL COMPETENCE AS THE BASIS OF PROFESSIONAL ACTIVITY OF FUTURE SOCIAL WORKERS
}

\section{Doroshenko Olga ${ }^{1}$}

DOI: https://doi.org/10.30525/978-9934-571-89-3_13

Today, the domestic pedagogical and social science faces a rather difficult task, namely the development of programs, methods for managing the process of becoming a person as a professional. And so, at the present stage of the development of society, the issue of the training of competent specialists in the social sphere that

${ }^{1}$ Black Sea National University named after Petro Mohyla, Ukraine 
could work not only in social services, but also directly with people of different categories, significantly increases. Until recently, a specialist was assessed according to his level of qualification. Today it is not enough to have a certain qualification, today it is necessary to be professionally competent, to have the ability and ability to solve the problems that are constantly arising in the course of their activity.

In psychological and pedagogical literature, considerable experience has been accumulated on the issue of competence, which was highlighted in the scientific works of N. Bibik, O. Bilyakovskaya, E. Bondarevskaya, B. Gershunsky, I. Zimnya, A. Khutorskogo, A. Shchekatunova, N. Roza, N. Zaprudsky and others. In the work of these authors, competence is associated with the level of education of the specialist and his general cultural competence, and also considered as a complex system, which includes knowledge, skills, skills and professional qualities of a specialist. The experience of this problem of foreign countries (E. Enwal, R. Garber, M. Gray, A. Kelly, D. Cocos, D. Maxwell, E. Wilkinson, E. Walsh) is very important for us.

The concept of "competence" in dictionaries is interpreted as "possession of knowledge, allowing to judge anything", "awareness of something", "authority, full power "And so on. Or, in the broadest sense of the word, "competent" (Latin competens, competentis - capable) means what "knows, experienced in a particular industry"; "who has the right, according to his knowledge, to judge anything". Increasing attention to this problem is associated with the emergence of a large group of people who need highly qualified social and psychological assistance professionals, namely social workers. Researchers on this issue are not unanimous in terms of the structure of the professional competence of a social worker and name more than a dozen of its components, in particular:

- erudition in the field of politics, economics, social development, culture;

- knowledge of the theoretical basis of the profession;

- ability to perform professionally determined actions;

- ability to make decisions and be responsible for their consequences;

- the ability to raise public interest in the results of their professional activities;

- sociability;

- professional tact and delicacy;

- emotional stability and readiness for psychological stresses;

- tolerance, benevolence and attention to people, etc. [1, p. 45].

In the works of F. Mukhametzyanova, another aspect of the structure of professional competence of a specialist in the social sphere is presented:

- socio-legal competence - knowledge and skills in the field of interaction with social institutions and people, as well as professional communication and behavior methods;

- special competence;

- the ability to solve typical professional tasks and evaluate the results of their work; the ability to independently acquire new knowledge and skills in the specialty;

- personal competence - the ability to continuous professional growth and professional development, as well as to implement itself in professional activities; 
- autocompetence - adequate representation of their socio-professional characteristics and possession of technologies to overcome professional destruction;

- extreme competence - the ability to act in extreme situations [2, p. 47].

Proceeding from the above, one can assume that most of the researchers in the social worker's professional competence comprise the necessary knowledge, skills, skills that coincides with the understanding of the "professional competence" category in their professional activity.

Having noticed the components of professional competence, one should pay attention to the fact that in modern conditions, future specialists need not only the availability of a certain set of professional knowledge in one or another field of activity, but also practical skills and skills that ensure the readiness to perform professional tasks and functions in different, sometimes even in non-standard situations [3, p. 21]. And the most crucial part in managing the competence of a social worker is his training at a higher educational institution. In order to make this process effective, it is necessary to adhere to the following conditions in the educational process:

- the development of curricula and programs on special disciplines on the basis of modern scientific views on the theory of social work, with an orientation on the values of social work as a professional activity;

- obligatory study of the experience of social work in all special disciplines and special courses;

- disclosure of the content of effective professional activities of a social worker in all types of educational work in higher education institutions;

- awareness of the subjective position of the future social worker;

- providing interconnection of content-procedural training and internal-personal formation of students' readiness for social work;

- the development of such personal qualities of students as orientation towards a person, the ability to effectively interact with another person and positively communicate with her, the desire for professional self-improvement, the creative nature of work;

- formation of students' needs and interests in preparing themselves for professional activity, their participation in research work in the field of social work and related disciplines;

- providing students with opportunities to participate in volunteering activities;

- the implementation of special training of employees of social institutions to the reception of trainees, their orientation to contacts and mutual cooperation [4, p. 177].

Only by creating these conditions in the educational process one can hope that the future professional activity of students in the specialty "social work" will be effective.

The professional success of a social worker is determined by the effectiveness of his work, and the result depends on the professional ability of a specialist. Competence is also an important condition for the success of a social worker and an indicator of his ability. The concept of "competence of a social worker" consists of a 
future specialist in the social sphere of professional knowledge, skills and abilities, personal qualities, and the ability to apply the acquired knowledge and skills in practice. The level of competence of a social worker is determined by the degree of formation of all these elements, in their successful combination.

\section{References:}

1. Brukhanova N. (2007). Pidkhody do rozuminnya kompetentnosti ta kompetentsiyi v osviti [Approaches to understanding competence and competence in education]. Pedagogy and psychology of vocational education, vol. 5, no. 4, pp. 40-49.

2. Gubareva O. (2005). Psykholohichni osoblyvosti formuvannya profesiynoyi kompetentnosti pratsivnykiv. [Psychological peculiarities of formation of professional competence of employees]. Kharkiv : Folio. (in Ukrainian)

3. Zimnyaya I. (2006). Kompetentnostnyy podkhod. Kakovo yego mesto v sisteme sovremennykh podkhodov k problemam obrazovaniya? [Competency approach. What is his place in the system of modern approaches to education? Higher education today, vol. 2, no. 8, pp. 20-26.

4. Raven Dzh. (2002). Kompetentnost' v sovremennom obshchestve: vyyavleniye, razvitiye i realizatsiya [Competence in Modern Society: Identification, Development and Implementation]. Moscow: Akademiya. (in Russian) 